\title{
Effect of Steel Fibers on Plastic Shrinkage Cracking of Normal and High Strength Concretes
}

\author{
$\ddot{O}_{z g \text { ür Eren }}{ }^{\mathrm{a}}$, Khaled Marar ${ }^{\mathrm{b}, *}$ \\ ${ }^{a}$ Department of Civil Engineering, Eastern Mediterranean University, \\ Gazimağusa, North Cyprus, Mersin 10, Turkey \\ ${ }^{\mathrm{b}}$ Department of Civil Engineering, European University of Lefke, \\ Gemikonağı-Lefke, North Cyprus, Mersin 10, Turkey
}

Received: July 6, 2009; Revised: March 5, 2010

\begin{abstract}
Naturally concrete shrinks when it is subjected to a drying environment. If this shrinkage is restrained, tensile stresses develop and concrete may crack. Plastic shrinkage cracks are especially harmful on slabs. One of the methods to reduce the adverse effects of shrinkage cracking of concrete is by reinforcing concrete with short randomly distributed fibers. The main objective of this study was to investigate the effect of fiber volume and aspect ratio of hooked steel fibers on plastic shrinkage cracking behavior together with some other properties of concrete. In this research two different compressive strength levels namely 56 and $73 \mathrm{MPa}$ were studied. Concretes were produced by adding steel fibers of 3 different volumes of 3 different aspect ratios. From this research study, it is observed that steel fibers can significantly reduce plastic shrinkage cracking behavior of concretes. On the other hand, it was observed that these steel fibers can adversely affect some other properties of concrete during fresh and hardened states.
\end{abstract}

Keywords: high strength concrete, plastic shrinkage, cracks, bleeding, fiber reinforced concrete

\section{Introduction}

High strength concrete (HSC) is generally accepted as a concrete having a compressive strength above $55 \mathrm{MPa}$ according to ACI Committee $363^{[1]}$. The main parameters to produce HSC are low porosity, achieved by using cement content greater than $400 \mathrm{~kg} \cdot \mathrm{m}^{-3}$, well graded aggregates, low water/cement ratios, adequate compaction and curing, and addition of superplasticizers to achieve workable $\mathrm{mix}^{2}$. HSC is a brittle material and brittleness can be reduced by the addition of short discrete fibers randomly distributed in concrete. The effect of fibers on the mechanical behavior of high strength fiber reinforced concrete is governed by the volume of fibers, aspect ratio of fibers, and bond between cementitious matrix and fibers ${ }^{3}$.

Plastic shrinkage occurs at early age, before it is set and has still not attained sufficient tensile strength. It occurs mainly due to loss of water from the surface of concrete ${ }^{4,5}$, that will lead to formation of water menisci that exert contraction forces within the microstructure ${ }^{4,6}$. The common remedy to reduce early age shrinkage is to avoid drying by proper handling of concrete especially in the first few hours after casting ${ }^{7,8}$.

The extent of shrinkage of concrete depends on many factors, including the properties of the material, temperature and relative humidity of the environment, the age when concrete is subjected to drying environment, and the size of the structure. If concrete is constrained from shrinkage, tensile stresses then develop and concrete may crack and hence may lead to a serious reduction in the durability of concrete. One of the major contributions of adding short, discrete fibers to concrete is the reduction in plastic shrinkage.

Shrinkage cracking of concrete is also a major problem in concrete members with large surface areas, such as bridge decks, slabs on grade, tunnel linings, thin surface repairs and floor slabs 9 . The potential for early age cracking is affected by the shrinkage magnitude, rate, degree of structural restraint, age of material, and structural geometry ${ }^{10}$.

Different methods and techniques for simulating and studying of plastic shrinkage cracking have been used such as slabs, rings, etc.

Soroushian et al. ${ }^{11}$ investigated the effects of collated fibrillated polypropylene fibers on the plastic shrinkage cracking of concrete slabs. They concluded that (a) fibers reduced the total plastic shrinkage crack area and maximum crack width at fiber volume of $0.1 \%$, (b) the total plastic shrinkage crack areas were less than those with $13 \mathrm{~mm}$ fibers only at 0.1 and $0.2 \%$ fiber volume, but not at $0.05 \%$ fiber volume, (c) the $19 \mathrm{~mm}$ fibers had 13,57, and 55\% less crack areas than $13 \mathrm{~mm}$ fibers at $0.05,0.1$, and $0.2 \%$ fiber volume, respectively, (d) the maximum crack widths with $19 \mathrm{~mm}$ fibers were 47,33 , and $36 \%$ less than those for $0.05,0.1$, and $0.2 \%$ fiber volume, respectively.

Sivakumar and Santhanam ${ }^{6}$ studied the behavior of hybrid combinations of steel and non-steel fibers of volume up to only $0.5 \%$ in controlling plastic shrinkage cracks of high strength silica fume concrete. They observed that the hybrid fiber concretes showed better crack control features than steel fibers alone, and the total crack area was reduced with increased addition of non-steel fibers, but the increase in non-steel fibers caused a decrease in the workability and resulted in harsh concrete mix that required high compaction energy due to balling and trapping of free water. They concluded that plastic shrinkage cracks were reduced by $50-99 \%$ compared to plain concrete, the steel-polyster combination caused crack reduction of $99 \%$, and the steel-glass combination did not perform well as the others due to the high stiffness of glass fibers were not able to contribute at low stress levels causing early age cracking. In this research mainly the effect of fiber volume up to $0.5 \%$ on the plastic shrinkage cracking was studied. 
Bayasi and McIntyre ${ }^{12}$ studied the effects of polypropylene fibers and silica fume on shrinkage plastic cracking in concrete. They have observed that the fibers reduced the evaporation/bleeding rate by $10 \%$, without a major effect of fiber volume, and also the bleeding rate for the fresh concrete with $10 \%$ silica fume was much lower than that of similar concrete without silica fume.

Naaman et al. ${ }^{13}$ investigated the plastic shrinkage cracking by using prismatic concrete specimens. Polypropylene, polyethylene, carbon and polyvinyl acetate fibers were used. The different fibers were evaluated at different volume fractions ranged from 0.05 to $0.4 \%$. They concluded that (a) the volume fraction and fiber diameter were most effective in controlling plastic shrinkage cracking, (b) changing the fiber length or aspect ratio had small effect on plastic shrinkage cracking, (c) at fiber volume of $0.2 \%$, most fibers with less than $0.04 \mathrm{~mm}$ diameter reduced plastic shrinkage of concrete by $10 \%$ compared to plain concrete. It was not clear if the fiber- matrix bond was the key parameter to reduce plastic shrinkage cracking.

Banthia and Gupta $^{9}$ searched the effect of polypropylene fiber diameter, fiber length and geometry on the plastic shrinkage in concrete. Three types of monofilament and one type of fibrillated polypropylene fibers were used. Three volume fractions of $0.1,0.2$, and $0.3 \%$ were used for each fiber type. The crack characterization was assessed by using a high magnification microscope. They concluded that (a) the longer fiber is more effective in reducing crack area, maximum crack width and number of cracks, (b) finer fibers were more effective than coarser ones because they have larger surface area over which it would bond with the cementitious matrix, hence more transfer of tensile stress to the fiber.

The primary objective of the study described in this paper was to investigate the effect of fiber volume and aspect ratio of hooked-end steel fibers on the plastic shrinkage cracking behavior: effect of fiber aspect ratio and fiber volume on water evaporation rate and first crack initiation time; relationships between fiber volume and plastic shrinkage crack length, plastic shrinkage crack width, and plastic shrinkage crack area for normal and high strength concretes.

\section{Experimental Program}

\subsection{Materials used}

In this study, steel fiber reinforced concrete (SFRC) mixes were made of Ordinary Portland ${ }^{\circledR}$ Cement (class 52.5), crushed limestone aggregates, superplasticizer, and hooked-end steel fibers of three different aspect ratios $(55,65$, and 80). Aggregates were designated as grade $1,2,3$, and 4 with maximum sizes of $20,14,10$, and $5 \mathrm{~mm}$, respectively. The specific gravities of grade 1, 2, 3, and 4 are 2.68, 2.67, 2.68, and 2.68, respectively. Aggregates were used as all-in aggregate. Superplasticizer (high range water reducing admixture) was used at a dosage of $0.8 \%$ by weight of cement. Three different steel fiber volumes of $0.5,1.0$, and $1.5 \%$ (by volume of concrete) were added (i.e. $39.25,78.5$ and $117.75 \mathrm{~kg} \cdot \mathrm{m}^{-3}$ ).

\subsection{Mixture proportions and mixing procedure}

Proportioning of mixtures is as shown in Table 1. Dry ingredients (aggregates and cement) were mixed in the mixer for 30 seconds. After that, steel fibers were added for 30 seconds. Then water (with superplasticizer) was added gradually in 15 seconds and the mixing continued for 2 minutes. Therefore, the total mixing time was 3 minutes for each concrete mixture.

\subsection{Experiments on fresh concrete}

The workability of freshly mixed concrete was assessed by using $\mathrm{VeBe}$ consistometer. The fresh unit weight of concrete was also measured and all the specimens were compacted in molds by means of a vibrating table. Bleeding of concrete was measured in accordance with ASTM C 232 - 92. An average of three readings was taken to represent data points for fresh concrete properties.

\subsection{Compressive strength of concrete}

Compressive strength was measured at 28 days on $150 \mathrm{~mm}$ cubes cured at $23 \pm 1{ }^{\circ} \mathrm{C}$ and $100 \%$ relative humidity. The average compressive strength was obtained on three cubes for each mix (total of 20 mixes).

\subsection{Plastic shrinkage cracking test procedure}

The following test procedure was successfully used by Soroushian, Mirza, and Alhozaimy ${ }^{11}$, Bayasi and Mclntyre ${ }^{12}$, Kraii ${ }^{14}$, and Shaeles and Hover ${ }^{15}$.

Two rectangular $840 \times 540 \mathrm{~mm}$ slabs with $40 \mathrm{~mm}$ thickness (plywood base and metal edges) were cast side by side and exposed to identical finishing processes and environmental conditions such as temperature, humidity, and wind velocity (Figure 1a). The temperature during testing ranged between 24 to $27^{\circ} \mathrm{C}$ and the relative humidity (RH) was kept $60 \pm 5 \%$, while the wind speed was $18 \mathrm{~km} / \mathrm{h}$ by utilizing fans. The fans were started 25 minutes after the addition of water to dry materials placed in the concrete mixer for all test slabs. Two $140 \mathrm{~mm}$-diameter metal molds were located next to slab specimens to measure the water evaporation rate from the fresh concrete surface. Two plastic containers filled with water were also placed in front of the slabs to determine the water evaporation rate. The procedure of plastic shrinkage crack measurement was as follows:

After mixing, fresh concrete was placed in the slab molds. Screeding was applied directly to the fresh concrete surface after placing. This was done by using a sawing motion of a metal straightedge, moving across the short direction of concrete sample surface. Following screeding, a bullfloat was applied to the fresh slab surface to eliminate high and low spots and to embed large aggregate particles at the surface. Hand-floating was then applied in conjunction with filling holes and smoothing ridges to give the slab a dense and smooth appearance. Troweling was finally applied after the bleed water started to evaporate.

Shrinkage cracks were measured 5.5 hours after concrete placement. Hand-held microscope and Planimeter (Figure $1 \mathrm{~b}$ and $\mathrm{c}$ ) were used to

Table 1. Mix proportioning and mix designation of concrete mixes.

\begin{tabular}{|c|c|c|c|c|c|c|c|c|}
\hline \multirow{3}{*}{$\begin{array}{l}\text { Concrete } \\
\text { series }\end{array}$} & \multirow{3}{*}{$\begin{array}{l}\text { Cement } \\
\left(\mathrm{kg} \cdot \mathrm{m}^{-3}\right)\end{array}$} & \multirow{3}{*}{$\begin{array}{l}\text { Superplasticizer } \\
\left(\mathrm{kg} \cdot \mathrm{m}^{-3}\right)\end{array}$} & \multirow{3}{*}{$\begin{array}{c}\text { Water } \\
\left(\mathrm{kg} \cdot \mathrm{m}^{-3}\right)\end{array}$} & \multirow[t]{3}{*}{$\mathrm{W} / \mathrm{C}$ ratio } & \multicolumn{4}{|c|}{ Aggregate $\left(\mathrm{kg} \cdot \mathrm{m}^{-3}\right)$} \\
\hline & & & & & \multicolumn{3}{|c|}{ Coarse aggregate } & \multirow{2}{*}{$\begin{array}{c}\text { Fine aggregate } \\
\text { Type } 4 \\
<5 \mathrm{~mm}\end{array}$} \\
\hline & & & & & $\begin{array}{l}\text { Type } 1 \\
20 \mathrm{~mm}\end{array}$ & $\begin{array}{l}\text { Type } 2 \\
14 \mathrm{~mm} \\
\end{array}$ & $\begin{array}{l}\text { Type } 3 \\
10 \mathrm{~mm}\end{array}$ & \\
\hline A & 450 & 3.60 & 241 & 0.54 & 202 & 369 & 353 & 756 \\
\hline B & 560 & 4.48 & 239 & 0.43 & 190 & 347 & 331 & 708 \\
\hline
\end{tabular}




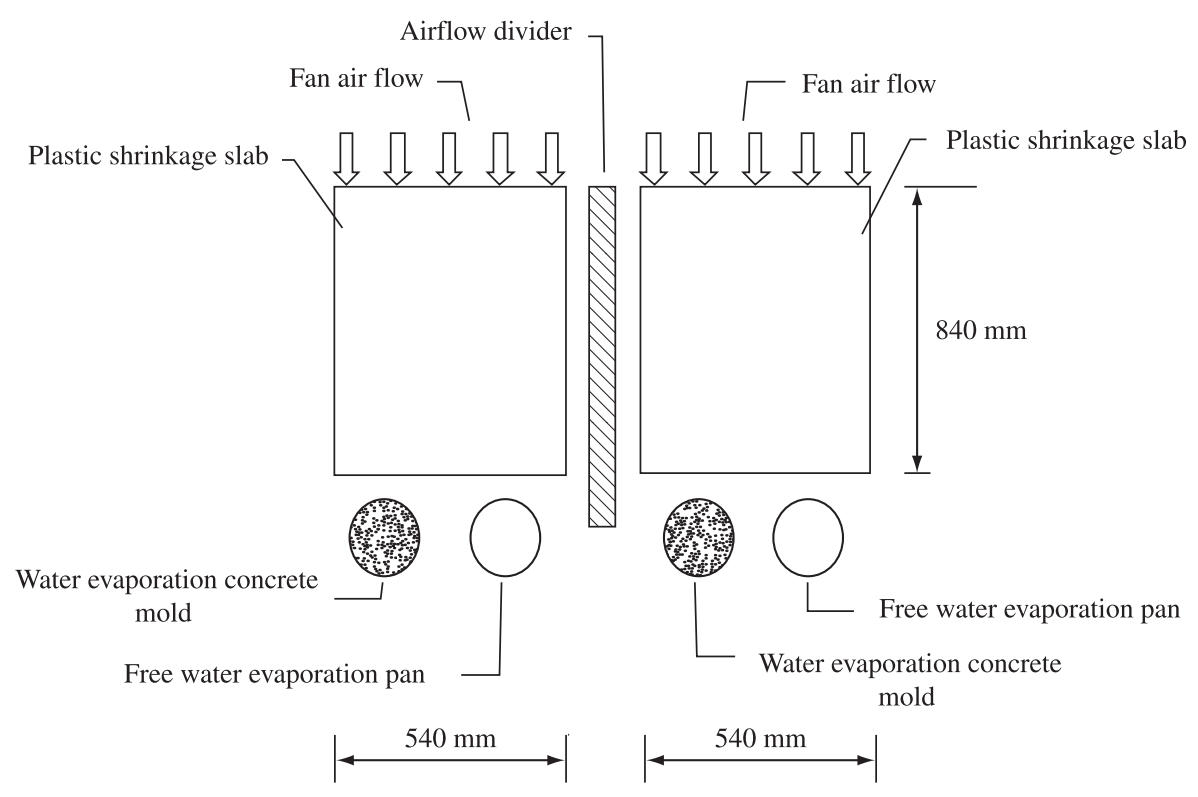

(a)

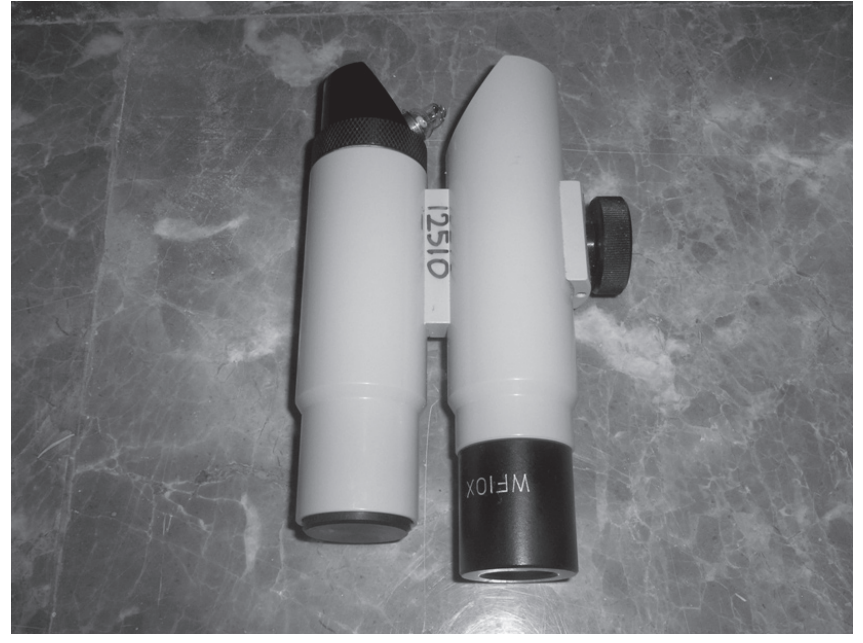

(b)

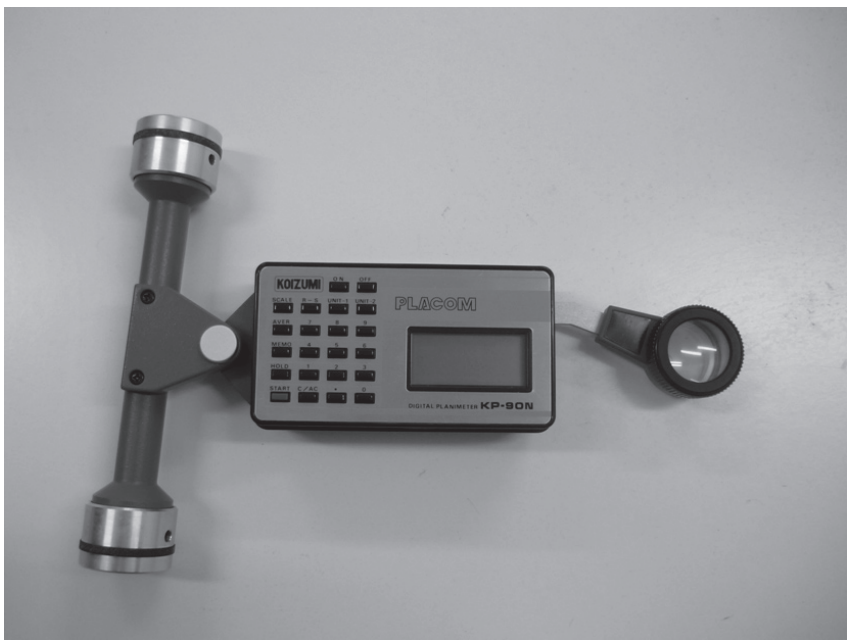

(c)

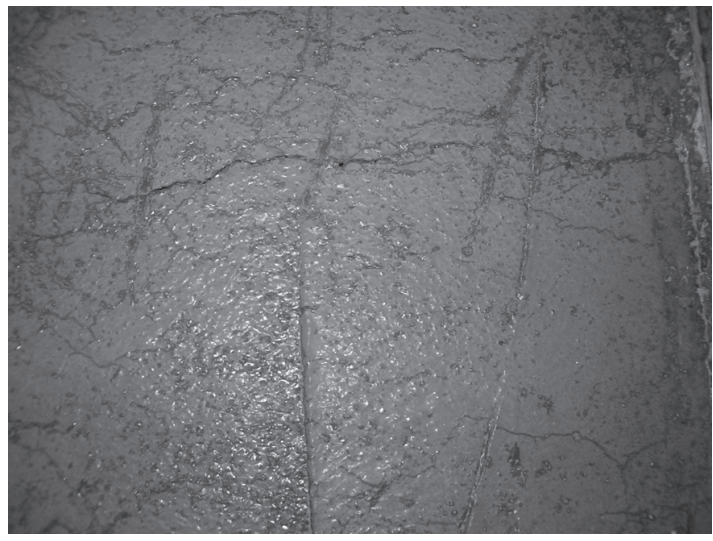

(d)

Figure 1. a) plastic shrinkage test panels; b) hand-held microscope; c) planimeter; and d) plastic shrinkage cracks patterns on fiber reinforced slab specimen. 
measure crack width and crack length, respectively. The crack length was measured accurately by tracing the planimeter along the crack lines. After these measurements crack width was also recorded by the hand-held microscope. The total crack area was calculated by summation of the products of total crack length by the average crack width for each slab. The average values were calculated considering two slabs for each mix. These are shown in Table 3. Figure 1d shows plastic shrinkage cracks patterns on fiber reinforced slab specimen.

\section{Results and Discussions}

\subsection{Fresh concrete}

The results of VeBe time, wet density, and amount of bleeding water test results are given in Table 2. Generally, as fiber volume increases, VeBe time increases for all aspect ratios. Also increasing fiber volume increases the wet density of fresh concrete slightly for all concrete series.

A significant reduction in water bleeding was observed for concrete series B compared to concrete series A for all concretes. This may be due to high amount of cement in concrete series B compared to series A. Samman et al. ${ }^{16}$ also showed that high-strength concrete mixes containing high proportions of cement produces concrete with low bleeding rates. For the case of 55 aspect ratio it seems that for both concrete series, as fiber volume increases, bleeding reduces. This can be due to fibers which block passage of water through voids. For other aspect ratios there is no clear behavior. Bayasi and $\mathrm{McIntyre}^{12}$ reported that fibers can reduce the rate of bleeding even at very low fiber contents.

\subsection{Hardened concrete}

Results of compressive strength are given in Table 2. Generally as fiber volume increases compressive strength reduces. This could be due to difficulties coming from achieving good compaction. Similar results were also reported by Eren et al. ${ }^{2}$.

\subsection{Plastic shrinkage cracking}

Results of plastic shrinkage cracking are presented in Table 3.

\subsubsection{Water evaporation rate and first crack initiation time}

Results of water evaporation rate and first crack initiation time are given in Table 3. Figure 2 and 3 show the effect of fiber volume and aspect ratio on water evaporation rate and first crack initiation time for concrete series A and series B, respectively.

It was observed that first crack initiation time for series B plain concrete is two times higher compared series A plain concrete. This could be due to high water/cement ratio of series A concrete. Evaporation rate of series A concrete was much higher than series B concrete and this caused an earlier first crack initiation time.

For series B concretes, all fiber reinforced concretes show lower first crack initiation time compared to the plain concrete (series B concrete).

For series B concretes, all fiber reinforced concretes show higher water evaporation rate compared to plain concrete (series B concrete). This could be due to development of preferential bleeding channels along the fiber which supply water to replenish the drying surface and reduce the magnitude of capillary stress. Similar finding ware also reported by Qi et al. ${ }^{17}$.

Fiber aspect ratio and fiber volume have no clear effect on water evaporation rate and first crack initiation time.

\subsubsection{Plastic shrinkage vs. fiber volume}

Figures 4-6 show the relationship between fiber volume and plastic shrinkage crack length, fiber volume and plastic shrinkage crack width, and fiber volume and plastic shrinkage crack area for all

Table 2. Vebe time, wet density, compressive strength, and amount of bleeding water test results.

\begin{tabular}{|c|c|c|c|c|c|c|}
\hline $\begin{array}{l}\text { Concrete } \\
\text { series }\end{array}$ & $\begin{array}{l}\text { Aspect ratio } \\
(1 / d)\end{array}$ & $\begin{array}{c}\text { Fiber volume } \\
(\%)\end{array}$ & $\begin{array}{l}\text { Vebe time } \\
\text { (seconds) }\end{array}$ & $\begin{array}{l}\text { Wet density } \\
\left(\mathrm{kg} \cdot \mathrm{m}^{-3}\right)\end{array}$ & $\begin{array}{c}\text { Amount of } \\
\text { bleeding water }(\mathrm{mL})\end{array}$ & $\begin{array}{c}\text { Compressive } \\
\text { Strength-28 days (MPa) }\end{array}$ \\
\hline \multirow[t]{10}{*}{ A } & - & 0.0 & 2.3 & 2297 & 23.00 & 56.13 \\
\hline & 55 & 0.5 & 3.0 & 2326 & 23.25 & 52.25 \\
\hline & 55 & 1.0 & 5.25 & 2345 & 9.25 & 54.50 \\
\hline & 55 & 1.5 & 13.2 & 2378 & 12.75 & 56.43 \\
\hline & 65 & 0.5 & 4.1 & 2330 & 9.00 & 54.87 \\
\hline & 65 & 1.0 & 14.3 & 2408 & 12.00 & 54.90 \\
\hline & 65 & 1.5 & 26.46 & 2422 & 28.50 & 52.20 \\
\hline & 80 & 0.5 & 4.5 & 2338 & 38.00 & 53.63 \\
\hline & 80 & 1.0 & 15.7 & 2399 & 6.25 & 54.83 \\
\hline & 80 & 1.5 & 30.41 & 2417 & 3.75 & 54.07 \\
\hline \multirow[t]{10}{*}{ B } & - & 0.0 & 3.8 & 2332 & 1.25 & 73.25 \\
\hline & 55 & 0.5 & 4.7 & 2363 & 1.00 & 68.00 \\
\hline & 55 & 1.0 & 8.0 & 2383 & 0.70 & 69.01 \\
\hline & 55 & 1.5 & 16.0 & 2413 & 0.50 & 70.50 \\
\hline & 65 & 0.5 & 6.03 & 2372 & 0.20 & 71.20 \\
\hline & 65 & 1.0 & 18.0 & 2418 & 2.00 & 72.60 \\
\hline & 65 & 1.5 & 29.56 & 2444 & 1.00 & 73.00 \\
\hline & 80 & 0.5 & 6.10 & 2375 & 0.50 & 69.00 \\
\hline & 80 & 1.0 & 17.32 & 2437 & 1.50 & 67.00 \\
\hline & 80 & 1.5 & 32.62 & 2452 & 1.25 & 67.00 \\
\hline
\end{tabular}


Table 3. Plastic shrinkage cracking test results.

\begin{tabular}{|c|c|c|c|c|c|c|c|c|c|c|c|c|}
\hline Series & $\begin{array}{c}\text { Aspect } \\
\text { ratio } \\
(1 / d)\end{array}$ & $\begin{array}{c}\text { Volume } \\
\text { of fibers } \\
(\%)\end{array}$ & $\begin{array}{c}\text { Number } \\
\text { of } \\
\text { cracks }\end{array}$ & $\begin{array}{c}\text { First crack } \\
\text { initiation } \\
\text { time } \\
\text { (minutes) }\end{array}$ & $\begin{array}{c}\text { Water evaporation } \\
\text { rate from } \\
\text { fresh concrete } \\
\left(\mathrm{kg} \cdot \mathrm{m}^{-2} / \mathrm{h}\right)\end{array}$ & $\begin{array}{c}\text { Total } \\
\text { cracks } \\
\text { length, } \\
(\mathrm{mm})\end{array}$ & $\begin{array}{l}\text { Average } \\
\text { crack } \\
\text { width } \\
(\mathrm{mm})\end{array}$ & $\begin{array}{l}\text { Max. } \\
\text { crack } \\
\text { length } \\
(\mathrm{mm})\end{array}$ & $\begin{array}{l}\text { Max. } \\
\text { crack } \\
\text { width } \\
(\mathrm{mm}) \\
\end{array}$ & $\begin{array}{c}\text { Total } \\
\text { cracked } \\
\text { area } \\
\left(\mathrm{mm}^{2}\right)\end{array}$ & $\begin{array}{c}* \text { Cracking } \\
\text { ratio } \\
(\%)\end{array}$ & $\begin{array}{c}* * \text { Reduction } \\
\text { of plastic } \\
\text { shrinkage } \\
\text { cracking }(\%)\end{array}$ \\
\hline \multirow[t]{10}{*}{ A } & - & 0.0 & 14 & 25 & 0.724 & 3366 & 0.090 & 524 & 0.52 & 306.95 & 100.00 & - \\
\hline & 55 & 0.5 & 25 & 30 & 0.618 & 2590 & 0.110 & 176 & 0.32 & 285.10 & 92.88 & 7.12 \\
\hline & 55 & 1.0 & 28 & 23 & 0.708 & 2267 & 0.120 & 314 & 0.40 & 272.04 & 88.63 & 11.37 \\
\hline & 55 & 1.5 & 22 & 12 & 0.738 & 2129 & 0.090 & 250 & 0.30 & 192.04 & 62.56 & 37.44 \\
\hline & 65 & 0.5 & 45 & 15 & 0.784 & 2258 & 0.102 & 250 & 0.40 & 239.28 & 77.95 & 22.05 \\
\hline & 65 & 1.0 & 47 & 15 & 0.799 & 1933 & 0.104 & 220 & 0.54 & 200.55 & 65.34 & 34.66 \\
\hline & 65 & 1.5 & 31 & 25 & 0.708 & 1233 & 0.110 & 135 & 0.30 & 131.66 & 42.89 & 57.11 \\
\hline & 80 & 0.5 & 41 & 25 & 0.693 & 2055 & 0.120 & 150 & 0.60 & 246.59 & 80.33 & 19.67 \\
\hline & 80 & 1.0 & 37 & 20 & 0.784 & 2166 & 0.090 & 150 & 0.30 & 194.75 & 63.45 & 36.55 \\
\hline & 80 & 1.5 & 23 & 28 & 0.738 & 875 & 0.093 & 100 & 0.25 & 79.96 & 26.05 & 73.95 \\
\hline \multirow[t]{10}{*}{$\mathrm{B}$} & - & 0.0 & 63 & 50 & 0.512 & 2571 & 0.230 & 176 & 1.00 & 700.43 & 100.00 & - \\
\hline & 55 & 0.5 & 53 & 33 & 0.558 & 1919 & 0.210 & 90 & 0.50 & 407.52 & 58.18 & 41.82 \\
\hline & 55 & 1.0 & 72 & 37 & 0.558 & 2802 & 0.130 & 140 & 0.32 & 367.88 & 52.52 & 47.48 \\
\hline & 55 & 1.5 & 44 & 30 & 0.588 & 1849 & 0.110 & 125 & 0.30 & 202.46 & 28.90 & 71.10 \\
\hline & 65 & 0.5 & 78 & 40 & 0.573 & 2594 & 0.142 & 85 & 0.55 & 370.54 & 52.90 & 47.10 \\
\hline & 65 & 1.0 & 45 & 22 & 0.588 & 2341 & 0.140 & 170 & 0.35 & 322.99 & 46.11 & 53.89 \\
\hline & 65 & 1.5 & 44 & 35 & 0.573 & 1684 & 0.120 & 162 & 0.30 & 201.12 & 28.71 & 71.29 \\
\hline & 80 & 0.5 & 77 & 48 & 0.648 & 2918 & 0.140 & 95 & 0.42 & 416.54 & 59.47 & 40.53 \\
\hline & 80 & 1.0 & 46 & 35 & 0.603 & 1981 & 0.120 & 120 & 0.30 & 239.56 & 34.20 & 65.80 \\
\hline & 80 & 1.5 & 46 & 41 & 0.618 & 1866 & 0.120 & 100 & 0.30 & 210.35 & 30.03 & 69.97 \\
\hline
\end{tabular}

* Cracking ratio relative to plain concrete; ** Reduction of plastic shrinkage cracking with respect to plain concrete.

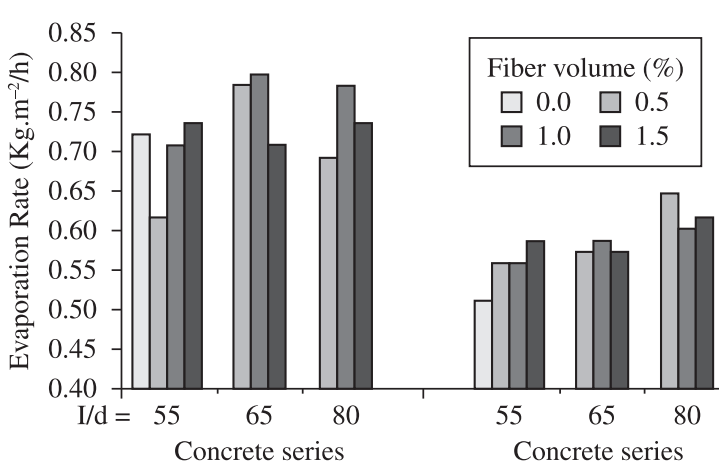

(a)

(b)

I/d: Fiber aspect ratio

Figure 2. Effect of fiber volume and fiber aspect ratio on water evaporation rate for series $\mathrm{A}$ and series $\mathrm{B}$ concretes.

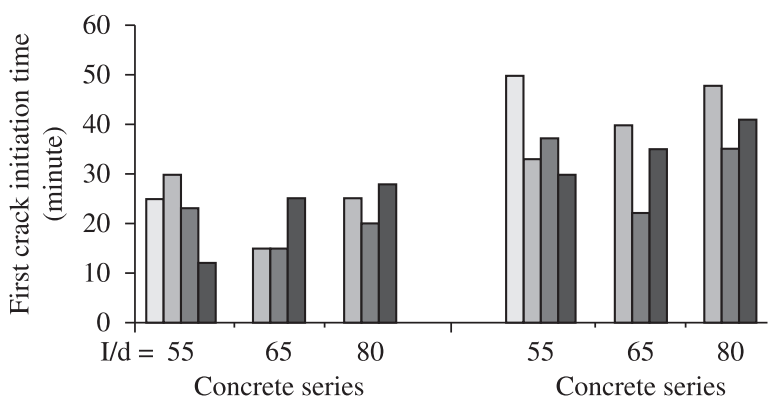

(a)

(b)

I/d: Fiber aspect ratio

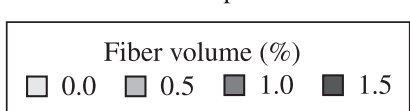

Figure 3. Effect of fiber volume and fiber aspect ratio on first crack initiation time for series A and series B concretes.

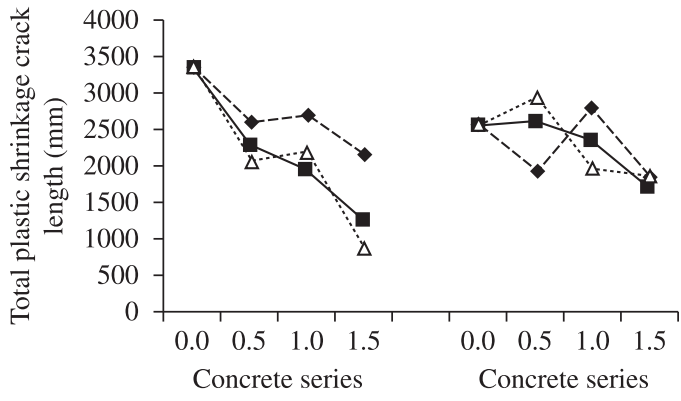

(a)

(b)

Fiber volume $(\%)$

Fiber aspect ratio $(\mathrm{I} / \mathrm{d})$

$55 \multimap 65--\triangle-\cdot 80$

Figure 4. Effect of fiber volume on total plastic shrinkage crack length ( $\mathrm{mm})$, for series A and series B concretes.

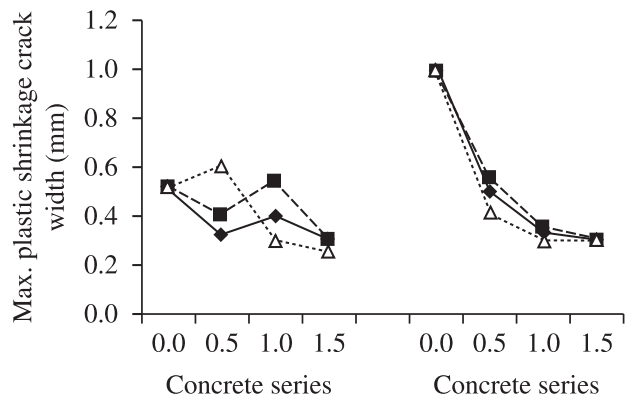

(a)

(b)

Fiber volume $(\%)$

Fiber aspect ratio $(\mathrm{I} / \mathrm{d})$

$55 \rightarrow-65--\Delta-80$

Figure 5. Effect of fiber volume on maximum plastic shrinkage crack width $(\mathrm{mm})$, for series A and series B concretes. 
concretes, respectively. A noticeable reduction in total crack length, maximum crack width and total crack area was observed when $1.5 \%$ volume of fibers was used for all aspect ratios for both concrete series. In most cases, increasing fiber volume causes a decrease in crack length, maximum crack width and total crack area. Fibers act as crack arrestors to minimize crack length, crack width and crack area.

For concrete series $\mathrm{B}$, increasing fiber aspect ratio with fiber volume fraction of $0.5 \%$ caused increase in total crack length (see Figure 4). However, at fiber volume fraction of $1 \%$, increases of aspect ratio causes a decrease in total crack length. For concrete series A with fiber volume of $1.5 \%$, increase in fiber aspect ratio causes a decrease in total crack length. These decreases were 42 and $59 \%$ when aspect ratios of fiber increased from 65 to 80 , respectively compared to concrete with aspect ratio of 55. It appeared that the fiber aspect ratio does not influence total crack length significantly. On the other hand it seems that the effective factor is the critical fiber volume, which is $1.5 \%$, for reducing the total crack length for both concrete series. Other researchers reported that the higher the volume of fibers, the better the control of plastic shrinkage cracking ${ }^{13}$, the lesser shrinkage contraction rate ${ }^{18}$, the more reduction in total crack area and maximum crack width ${ }^{19}$.

\subsubsection{Plastic shrinkage vs. fiber aspect ratio}

Figure 5 shows that the total plastic shrinkage crack area decreases as the fiber aspect ratio increases at fiber volume of 1.5 and $1 \%$, for concrete series A and series B, respectively. From Figure 5, it is clear that the fiber aspect ratio does not influence the maximum plastic shrinkage crack width.

\subsubsection{Plastic shrinkage vs. strength level}

As can be seen from Figure 5 and 6, Plain concrete having $73 \mathrm{MPa}$ (series B) compressive strength at 28 days has higher maximum crack width and total crack area than concrete with $56 \mathrm{MPa}$ (series A). This may be due to the high amount of cement content. It was also observed that from Figure 5, the maximum crack width for concrete series A is about half of the maximum crack width for concrete series B.

Shaeles and Hover ${ }^{15}$ investigated plastic shrinkage cracking in mortar panels and concluded that the incidence of plastic shrinkage cracking increased with the paste volume fraction.

\subsubsection{Total plastic shrinkage crack area vs. fiber volume}

Regression analyses provided a linear relationship between total plastic shrinkage crack area $\left(\mathrm{A}_{\mathrm{t}}\right)$ and fiber volume $\left(\mathrm{V}_{\mathrm{f}}\right)$. The test results of regression analyses are given in Table 4 . The relationship obtained as a result of regression analyses is as follows (Equation 1):

$$
A_{t}=a\left(V_{f}\right)+b
$$

Table 4. Regression analyses results between total plastic shrinkage crack area $\left(\mathrm{mm}^{2}\right)$ and fiber volume $(\%)$

\begin{tabular}{ccccc}
\hline \multirow{2}{*}{$\begin{array}{c}\text { Concrete } \\
\text { series }\end{array}$} & $\begin{array}{c}\text { Aspect } \\
\text { ratio }(1 / \mathrm{d})\end{array}$ & \multicolumn{2}{c}{ Regression coefficient } & $\begin{array}{c}\text { Correlation } \\
\text { coefficient }\left(\mathrm{R}^{2}\right)\end{array}$ \\
\hline $\mathrm{A}$ & 55 & -72 & 318 & 0.850 \\
& 65 & -113 & 304 & 0.989 \\
& 80 & -147 & 317 & 0.964 \\
$\mathrm{~B}$ & 55 & -307 & 650 & 0.913 \\
& 65 & -310 & 631 & 0.874 \\
& 80 & -329 & 639 & 0.894 \\
\hline
\end{tabular}

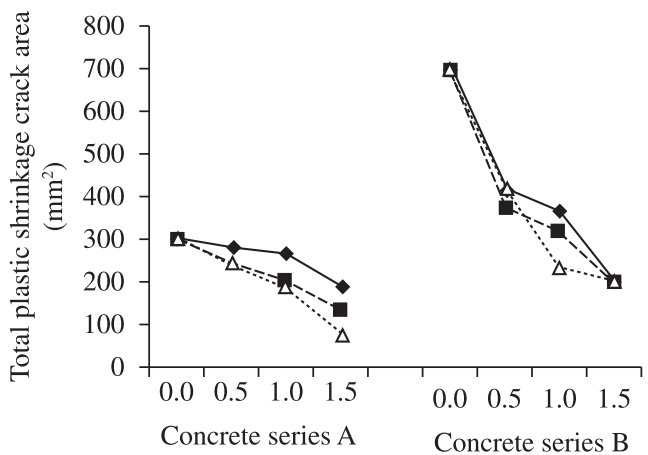

Fiber volume (\%)

Fiber aspect ratio (I/d)

$\rightarrow-55 \rightarrow-65--\Delta-80$

Figure 6. Effect of fiber volume on total plastic shrinkage crack area $\left(\mathrm{mm}^{2}\right)$, for series A and series B concretes.
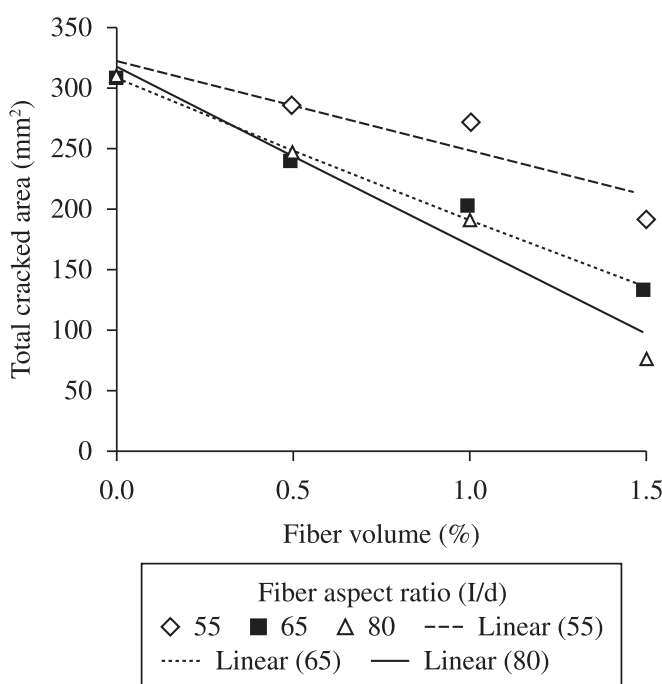

Figure 7. Total plastic shrinkage crack area as function of fiber volume (\% by volume of concrete) for concrete series A.

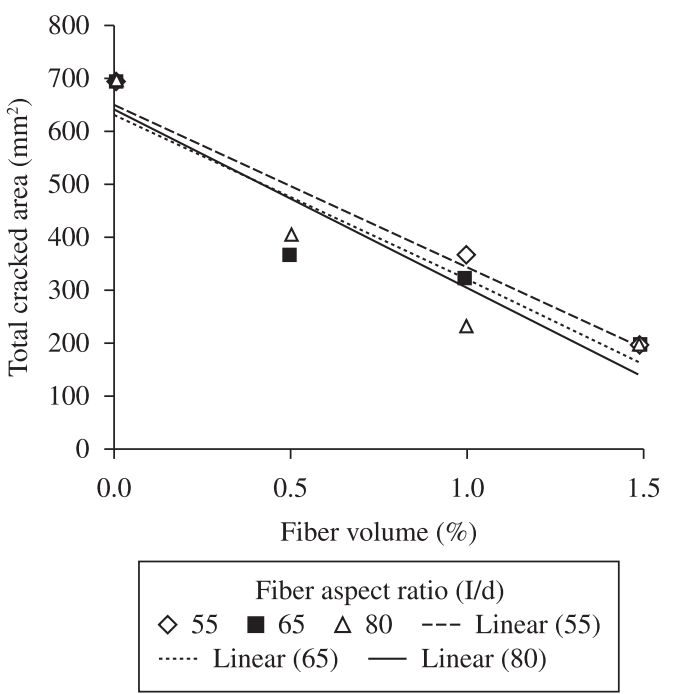

Figure 8. Total plastic shrinkage crack area as function of fiber volume (\% by volume of concrete) for concrete series B. 
Where $A_{t}$ is total plastic shrinkage crack area $\left(\mathrm{mm}^{2}\right), V_{\mathrm{f}}$ is fiber volume (\%), a and $\mathrm{b}$ are regression coefficient.

Experimental data points and regression lines are shown together in Figures 7 and 8. From Figures 7 and 8, it can be seen that there is a linear relationship between total plastic shrinkage crack area and fiber volume. The total crack area seemed to decrease with an increase in the fiber volume fraction due to the reduction in the crack widths. From correlation coefficient results it can be said that there is a good relationship between total plastic shrinkage crack area and fiber volume as most of the correlation coefficients are above 0.85 .

\section{Conclusions}

- In general, addition of fibers increases VeBe time and wet density of fresh concrete.

- A significant reduction in water bleeding is observed for concrete series B compared to concrete series A for all concretes.

- It was observed that first crack initiation time for series B plain concrete is two times higher compared series A plain concrete.

- Fiber aspect ratio and fiber volume have no clear effect on water evaporation rate and first crack initiation time.

- It seems that fiber aspect ratio does not influence total crack length significantly.

- There is a critical fiber volume content of fibers to reduce the total crack length for both concrete series.

- There is a linear relationship between total plastic shrinkage crack area and volume percentage of steel fibers.

\section{References}

1. ACI committee 363, State of the art report on High-Strength Concrete. In ACI Manual of Concrete Practice (MCP). Farmington Hills: American Concrete Institute; 2002. ACI 363R-92.

2. Eren Ö, Marar K and Çelik T. Effects of silica fume and steel fibers on some mechanical properties of high-strength fiber-reinforced concrete. Journal of Testing and Evaluation (ASTM). 1999; 27(6):380-387.

3. Marar K, Eren Ö and Çelik T. Relationship between impact energy and compressive toughness energy of high-strength fiber-reinforced concrete. Materials Letters. 2001; 47(4-5):297-304.

4. Mora-Ruacho J, Gettu R and Aguado A. Influence of shrinkage-reducing admixtures on the reduction of plastic shrinkage cracking in concrete. Cement and Concrete Research. 2009; 39(3):141-146.
5. Jian S and Rongbing B. Synthesis and evaluation of shrinkage-reducing admixture for cementitious materials. Cement and Concrete Research. 2005; 35(3):445-448

6. Sivakumar A and Santhanam M. A quantitative study on the plastic shrinkage cracking in high strength hybrid fibre reinforced concrete. Cement and Concrete Composites. 2007; 29(7):575-581.

7. Holt E. Contribution of mixture design to chemical and autogenous shrinkage of concrete at early ages. Cement and Concrete Research. 2005; 35(3):464-472.

8. Boghossian E, Wegner LD. Use of flax fibres to reduce plastic shrinkage cracking in concrete. Cement and Concrete Composites. 2008; 30(10):929-937.

9. Banthia N and Gupta R. Influence of polypropylene fiber geometry on plastic shrinkage cracking in concrete. Cement and Concrete Research. 2006; 36(7):1263-1267.

10. Weiss WJ, Yang W and Shah SP. Influence of specimen size/geometry on shrinkage cracking of rings. Journal of Engineering Mechanics. 2000; 126(1):93-101.

11. Soroushian P, Mirza F, and Alhozaimy A. Plastic Shrinkage Cracking of Polypropylene Fiber Reinforced Concrete. ACI Materials Journal. 1995; 92(5):553-560.

12. Bayasi $Z$ and Mclntyre M. Application of Fibrillated Polypropylene Fibers for Restraint of Plastic Shrinkage Cracking in silica Fume Concrete. ACI Materials Journal. 2002; 99(4):337-344.

13. Naaman A, Wongtanakitcharoen $T$ and Hauser G. Influence of Different Fibers on PlasticShrinkage Cracking of Concrete. ACI materials Journal. 2005; 102(1):49-58.

14. Kraai PP. Proposed Test to Determine the Cracking Potential Due to Drying Shrinkage of Concrete. Concrete Construction. 1985; 30(9):775-778.

15. Shaeles $\mathrm{C}$ and Hover KC. Influence of Mix Proportions and Construction Operations on Plastic Shrinkage Cracking in Thin Slabs. ACI Materials Journal. 1988; 85(6):495-504.

16. Samman TA, Mirza WH and Wafa FF. Plastic shrinkage Cracking of Normal and High-Strength Concrete: A Comparative Study. ACI Materials Journal. 1996; 93(1):36-40.

17. Qi C, Weiss J and Olek J. Characterization of Plastic Shrinkage Cracking in Fiber Reinforced Concrete using Image Analysis and Modified Weibull Function. Materials and Structures. 2003; 36:386-395.

18. Sun $\mathrm{Z}$ and $\mathrm{Xu}$ Q. Microscopic, Physical and Mechanical Analysis of Polypropylene Fiber Reinforced Concrete. Materials Science and Engineering A. 2009; 527(1-2):198-204.

19. Boghossian E and Wegner LD. Use of Flax Fibers to Reduce Shrinkage Cracking in Concrete. Cement and Concrete Composites. 2008; 30(10):929-937. 